\title{
Volunteer peer supervision: In an ever-changing social service environment
}

\author{
Jason Rushton
}

Jason Rushton is a postgraduate student from the Postgraduate Diploma in Social Service Supervision and Master of Social Work programme at Massey University.

\section{Abstract}

The purpose of this article is to start a discussion around the importance of peer supervision with social service volunteers (New Zealand Federation of Voluntary Welfare Organisations [NZFVWO], 2001, pp. 61-63). This will be achieved by addressing the history of volunteerism and the rise of Charitable Trusts (Styles, 1979, pp. 86-88). The structure of volunteerism changed, as policymakers identified the importance of including specific volunteer's roles and functions in legislation. Furthermore, policymakers began introducing clarification around peer supervision and peer support, linking the importance of supervision for volunteerism in the social services (NZFVWO, 2001, pp. 61). The introduction of peer supervision for volunteers in the social services is to provide accountability around professional practice and registration for many social service professions. The importance of peer supervision for volunteers working in the social services should be viewed as a safeguard to provide better practice for the volunteer, client and agency (O'Donoghue, 1999, p. 7). Volunteering New Zealand (VNZ) offers an alliance with supporting agencies and government around volunteering best practice in the support and development of managers and coordinators of volunteers (VNZ, 2014, para 1-15). An example of this is the Volunteer Army, which came to fruition around the Christchurch earthquakes, getting the community working alongside each other to support and help those in need.

However, none of these professional bodies offer a code of ethics to provide guidelines to volunteers. The Aotearoa New Zealand Association of Social Workers (ANZASW) does offer a Code of Ethics, not only to social workers but to all social services and volunteers (Beddoe \& Randal, 1994, p. 31), which could be incorporated and used as a guideline. Although social work has a code of ethics guideline there is still some debate around mandatory registration to provide accountability and safeguard clients and social work practice.

\section{Introduction}

Volunteers in the social service sector play an integral part of providing a wraparound service. Recruiting volunteers has identified new ethical dilemmas around accountability towards safe practice to the public (Beddoe \& Randal, 1994, pp. 28-29; Boston, Dalziel \& St John, 1999, p. 305). The re-emergence of recruiting volunteers is due to individuals listening to their community's voice, identifying needs and offering services to fill these 
gaps (NZFVWO, 2001, p. 11). There are many individuals who wish to offer their support in order to fill some of these gaps (Volunteering New Zealand, 2014, p. 2; Ellis, 1999, p. 58), only to find out later that society has changed, and they need more support to continue in their roles. This is due to the ever-increasing trends of today's society requiring volunteers and professionals alike to be trained, accountable, offer anonymity and confidentiality, and, more importantly, working under an agency's umbrella that can regulate and offer these requirements (Court, 2012, para. 5-7). These trends are changing the way in which organisations take on volunteers, as they too are bound by legislation (NZFVWO, 2001, p. 21). It is now accepted that volunteers have the same rights as their employed counterparts. The question that needs to be addressed is, why is supervision not then offered or encouraged for volunteers who work in the social service sector? One of the requirements for funding from the Ministry of Social Development (MSD) is that social workers need to be working towards, or are already registered with, the Social Workers Registration Board (Ellis, 1999, p. 71; Tsui \& Cheung, 2009, p. 53; MSD, 2012b, p. 12). The conundrum is that social workers are not mandated under legislation to register or join a professional body (Lonne \& Duke, 2009, pp. 378-379), so it would be hard to include volunteers within this proposition.

\section{History of volunteerism in social services}

The earliest literature that encourages the use of volunteerism emerged from the social economic changes (O'Brien, 1999, p. 402) which impacted on peasants when they moved away from their farms and homes and migrated into towns in the belief that their lives would be better (Boston, 1999, pp. 5-7). This occurred due to the industrial revolution in Britain, which took place between the 1750s and 1830s, and which caused social and economic changes. These changes impacted on rural farmers who had to move into the towns to get better work (De Vries, 1994, p. 247; Giddens, 2009, p. 116). As towns became more populated and poverty increased due to lack of employment, social issues arose from malnutrition, diseases and shortage of housing. Looking at Maslow's Hierarchy of Needs, people's basic needs were not being met (Pearce \& Steiner, 2004, pp. 216-218), and charitable trusts emerged to fulfil those needs with support in the form of food-banks and providing shelter (Tennant, O'Brien \& Sanders, 2008, p. 20). As time progressed the charitable trust grew within communities and began addressing social needs. From these needs the social service profession emerged to fill the gaps in social service delivery (Dalziel \& St John, 1999, p. 83; O’Donoghue, 1999, p. 7; Tennant, 2004, p. 44; Tsui \& Cheung, 2009, p. 149). From these gaps, two prominent women arose, Mary Richmond and Jane Addams, who are recognised as two of the most influential figures in the history of the social work profession. Many social service organisations started to grow from their ideas, which mainly consisted of volunteers identifying individual and community needs, and pursuing local authorities, business and the public to help create and obtain funding to get these organisations off the ground (Clermont, 2011, pp. 3-8; Tennant et al., 2008, p. 19). For example, Jane Addams' settlement homes, the child benefit for mothers, and soup kitchens. As the organisations grew, the complexities within society emerged (Nash, 2009, p. 371) and the need for more qualified specialists, for example, social workers, counsellors, youth workers and other professionals, emerged (Tennant as cited in Tennant et al., 2008, p. 20). Volunteers in these areas began to diminish as they could no longer justify their support without being paid. This was due to World Wars and the changing environment of women working (Beddoe \& Randal, 1994, p. 21; Tennant, 2004, pp. 14-15). 


\section{Volunteerism in legislation}

In today's societies volunteers have the same rights as employed staff; however, the Employment Relations Act 2000 (s.3) does not clearly identify volunteers within the Act. Volunteers do have the same rights as employed staff (Department of Labour, n.d, para. 2). This could be viewed as a lack of political understanding around the roles of volunteers and the ever changing environment in which they work. The word 'volunteer' is clearly defined around Health and Safety in the Employment Act 1992 (Department of Labour, n.d., para. 3). The Act identifies the different types of volunteerism and their duties within an organisation. Furthermore, the Human Rights Act 1993 (s.23, 1(a)(b)(c)(d) \& 2) refers to the employee, either in paid or unpaid work and their rights as an individual. The Criminal Records Act 2004 plays an important part in recruiting (NZFVWO, 2001, pp. 37-40), and the Privacy Act 1993 is enshrined into organisations, procedures and policies ensuring that paid and un-paid employees alike are protecting the client and agency by means of anonymity and confidentiality (NZFVWO, 2001, p. 79; VNZ, 2014, para. 1-15). Interestingly, the Volunteers Employment Protection Act 1973 (s.2) does not include volunteers working for an agency. The Act only includes the Armed Forces of the New Zealand Defence Force and their operational roles in the Forces. Wash and Brosnan (1999, pp. 117-118) identifies The Employment Contracts Act 1991 which seems to be excluded from most literature identifying volunteers contracts, either single or collective, and their right to belong to a union.

\section{Peer supervision versus peer supports}

There seems to be a misconception between peer support and peer supervision. This can be clarified by identifying and addressing the different roles and functions of the two supports which takes place in the social service sector. Peer support includes two or more professions, for example, social workers and counsellors who support each other by sharing reciprocal knowledge and utilising critical practice models to enlighten their practice. These models are utilised to develop and maintain ongoing professional services to their profession, self and clients and can be used as a record for ongoing professional development (Beddoe \& Egan, 2009, p. 411). Whereas, peer supervision can be viewed as a reciprocal arrangement of sharing one's own personal experiences within a group, either of the same or different professions that work together for mutual benefit, where developmental feedback is emphasised and self-directed learning and evaluation is encouraged (King, Lloyd, Clune, \& Allan, 2009, pp. 74-75; Mataira, 1985, p. 21).

\section{Volunteer's professional body}

Generating a Google search for a 'code of ethics' for volunteers in New Zealand resulted in only identifing well-established organisations, their philosophies, policies which incorporated their mission statements and goals for volunteers. The search was not clear in finding any professional body that would embrace volunteers working in the social service sector. However, according to the Chief Executive, V. Dhiru, (personal communication June 9, 2014) Volunteer New Zealand (VNZ) has written a Code of Ethics for their Governance Board, also referred to as the Board of Trustees. This led to the quandary, would a 'code of ethics' for volunteers, ensure they could be held accountable for their actions? More importantly, how can a supervisor offer guidance to volunteers without a clear guide of their job role/ responsibilities? 
As there was a lack of guidance for supervision, a conversation took place with the General Manager and Projects Director of the Volunteer Army Foundation, J. Pemberton (personal communication, June 10, 2014) who acknowledged that he did not know of a code of ethics to follow. As social services move forward for more accountability and professionalism (Ellis, 1999, pp. 58-59), the question that needs to be asked is, 'what organisation or professional body should support volunteers in New Zealand?' Research has indicated that the most logical professional body to support volunteers in the social services is the ANZASW whose mission statement, 'promotes excellence in the social work profession. This is enhanced by the indigenous identity of Aotearoa New Zealand, for and on behalf of its members and their communities'(ANZASW, 2013, p. 4). However, to broaden their membership, the ANZASW should include or change the words 'social work' to 'social services' and by so doing encourage a larger membership. Therefore, it can be argued that volunteers working in the social service field should be provided with the same structures as social service employees by including and encouraging volunteers to join the ANZASW as a means of accountability and professional development (Harms \& Connolly, 2009, p. 11); and, more importantly, having guidelines around their practice by adhering to the ANZASW Code of Ethics (Beddoe \& Randal, 1994, p. 31; Ellis, 1999, pp. 60-61).

\section{Registration and accountability}

At present, social workers are not mandated to register their practice with the SWRB, or become a member of a professional body such as the ANZASW (Collins, 2008, p. 1188; SWRB, n.d., p. 12). Therefore, does this mean supervisors in the social services field do not need to be registered practitioners? This also leaves open the debate around the qualifications of supervisors (Dalley, 2004, p. 185), as the nature of supervision in itself is complex and cannot be defined as one single concept. There are many different facets to supervision; which is related to the type of employment being government or non-government agencies, the type of contract between supervisor and supervisee, and cultural components (Kane, 2001, pp. 299-300; Walsh-Tapiata \& Webster, 2004, p. 11). However, supervision in social services can be described as a contract between two or more individuals whereby the experienced supervisor supports the supervisee to ensure the quality of service to clients, agency or organisation (Tsui, 2004, pp. 9-11). Both the ANZASW and SWRB do not identify the level of qualification required when offering supervision. It is stated that social workers can only be supervised by other social workers (preferred registered) who have two or more years' practicum and have had some form of training in supervision (ANZASW, 2012, p. 4; SWRB, 2013, p. 4).

The importance of supervision within the social service sector has already been addressed. Therefore, it seems that supervision is moving towards anonymity by institutions offering a recognised qualification such as the Postgraduate Certificate in Professional Supervision through Wintec (Wintec, 2014, para. 1-2), Postgraduate Certificate in Professional Supervision through The University of Auckland (University of Auckland, 2014, para 1-3) and, at Massey University, the Postgraduate Diploma in Social Service Supervision (Massey University, 2014, para 1). The Office of the Chief Social Worker for Child, Youth and Family has addressed the need for increased structured supervision within the organisation. However, the Chief Social Worker has missed the opportunity in addressing these changes in his report 'Workload and Casework review' (2014, p. 17) around the type of supervision and the appropriate qualification needed to supervise his staff (Lonne \& 
Duke, 2009, p. 383). If the Chief Social Worker had included these changes, he would have sent a strong positive message that Child, Youth and Family are moving forward to having qualified practitioners trained at degree level or above while offering the best service to staff, organisation, community and client (Nash, 1994, p. 41). The knock-on effect would have filtered through the social services to include volunteers and their practice (Ellis, 1999, pp. 60-61), as qualified staff have a better knowledge and understanding to pass onto volunteers.

\section{Aotearoa New Zealand Association of Social Workers}

Historically, social work has been at the forefront of social service intervention (Payne, 2006, p. 1). This is mainly due to the nature of the profession interacting with individuals and supporting clients to change their own lives. According to Kadushin's management process in social service supervision, it is important to address accountability of best practice towards clients (Beddoe \& Randal, 1994, pp. 28-29). This allows more freedom to do the job autonomously, supported by a professional body encouraging accountability towards volunteers, client and agency (Ellis, 1999, p. 77; O’ Donoghue, 2012, p. 346).

One of the professional bodies is the ANZASW who are looking for ways to expand their membership (ANZASW, Christchurch Board Member, K. Brown, personal communication, August 1, 2014). However, there is no clear consensus around the ANZASW role or identifiable approaches in recruiting or promoting the volunteer sector (NZFVWO, 2001, pp. 37). Again, this leaves the sector vulnerable to unsafe practice, as social work itself is not yet mandated to protect the public's interest (Beddoe \& Randal, 1994, pp. 28-29; Ellis, 1999, pp. 73-74). Therefore, how can it be expected to encourage and enforce ethical practice with volunteers when the social work profession is not able to get their own house in order, by enforcing compulsory registration, even though the SWRB (2013, p. 4) wishes this to take place? One would have thought that accountability and safety to the public (NZFVWO, 2001, p. 79) would be paramount for any profession that is heavily financially supported by the MSD (Briggs \& Cromie, 2009, pp. 227-228). An oxymoron in the social work environment surrounds the Honourable Paula Bennet and her White Paper (MSD, 2012a, p. 9) that was encouraging social workers, either frontline or in schools, to be the first point of call in working with our most vulnerable children (Connolly, 2009, p. 58). In reality, the Minister did not endorse or enforce mandatory registration when she was in her role of Minister of Social Development (SWRB, 2011). This left social workers working towards a professional identify frustrated, as they felt the need to protect the profession and public (Jones, 1999, pp. 80-82). And how does this affect and transfer accountability into the volunteer sector? Chief Executive Officer of the ANZASW, L. Standford-Reid (personal communication May 13, 2014) identified that they do offer membership to volunteers in this sector. However, the fees are substantial for any agency to carry and more importantly for the volunteer to pay. These fees should be revisited by the ANZASW's Board by offering a lower tariff and providing more publicity around the importance of being engaged with a professional body and encourage more volunteers into the fold. Participation would allow accountability in the volunteer sector (Munford \& Nash, 1994, p. 11) by encouraging training, good practice standards, accountability and professionalism, and knowing that their health and safety concerns are being met. 


\section{Benefits of peer supervision}

A supervisor's aim is to provide a safe environment to identify and enhance valuable skills of supervisees through reflective practice (Weld, 2012, pp. 42-43). To promote a learning culture within the organisation by helping employed staff, volunteers gain competency to feel supported and valued (NZFVWO, 2001, p. 21). This will in turn provide the organisation with competent and effective staff. The supervisor's role is to provide examples on how to prevent problems and introduce standards of performance, behaviour and relationships between staff and volunteers (Bruce \& Austin, 2000, p. 95). Supervision enables the development of professional skills and installing competence in the supervisee, which can catch or prevent poor performance by identifying areas of concern (McNicoll, 2008, p. 2). It helps to recognise and address potential problems such as burnout and to identify problems before they become issues. Promoting reflective practice helps to keep staff happy within their jobs and encourages a low staff turnover (McNicoll, 2008, pp. 3-4):

\section{A guide for volunteer supervision}

Peer supervision usually takes place with a group of qualified professionals who have training in the field of supervision, or who have received supervision (ANZASW, 2008, p. 13; Tsui \& Cheung, 2009, p. 149). Regardless of the configuration of the group, it is important that peer supervision is constructed to fulfil the three main functions which are, managerial, educative and supportive (Kadushin as cited in Kane, 2001, pp. 295-296). The intention is to encouraging participants to work together in ways that achieve the specific purpose of supervision. The goal is to enable the development of professional skills and competence in the supervisee. Therefore, it is important to identify what parts of supervision are needed for the type of supervisee (Kane, 2001, pp. 295-296). The use of peer group supervision can add enormous rigour to the process if the group is using robust and well-designed supervision tools.

The importance of not having hierarchical structures within this format is foremost, as it takes away those that believe they are of higher standing than others. By allowing and encouraging every participant a voice allows change. The impact from other supervisees can provide support and an increase of knowledge by sharing their information, values and beliefs, as the clinician will offer the supervisees further clarity and offer one-on-one supervision if that is deemed necessary by protecting clients and self (ANZASW, 2008, pp. 8-11; Shulman, 2008; SWRB, 2008, p. 5). Therefore, in this case of volunteer supervision, it is important for a trained professional in the art of supervision to act as a facilitator in this role (Tsui, 2005, pp. 9-11; Munson, 1979, p. 180). This leaves the question, what type of supervision would be important for each supervisee? There are those that would suggest the management function would be redundant with supervisees, as this process may be a redundant function in this setting. This is due to in-house managers already taking on the role and making sure that supervisees adhere to policy and the day-to-day care of running an agency (NZFVWO, 2001, p. 23). The remaining two roles of supervision, educative and supportive, do and can stand alone (Bruce \& Austin, 2000, pp. 117-118).

Many supervisees working in social service agencies utilise their status in a learning capacity to further their careers. In this role the educative part of supervision plays an 
important part for supervisees (Hawkins \& Shohet, 1989, p. 66). Education can be achieved by in-house or external training volunteers receive to complete their employment task in the area of social services (NZFVWO, 2001, pp. 53-54). Therefore, an educational role can be viewed as obtaining theory and technical skills around their current environment by processing the content in which it happens to develop self-awareness and insight. Whereas, the supportive role will play a pivotal part to volunteer supervision by validating their importance and making sure they are working in a safe environment (Ellis, 1999, p. 63). The debriefing and reflective part of supervision for supervisees can be viewed as the most important part of supervision, as it allows the volunteer to process any issue brought to supervision, and encourages group discussions and reflections on past and present knowledge to achieve problem solving (Hawkins \& Shohet, 1989, p. 96). Many managers would presume those frontline volunteers who are engaged with clients on a daily basis, for example, volunteers providing food-parcels would not be affected by their daily interaction with clients (Ellis, 1999, pp. 64-65). However, there is more than just a simple exchange of words and actions. The client usually talks about their living situation, how they are struggling financially to make ends meet, or having social issues with family and friends, finding themselves isolated and alone. This leaves the supervisees thinking that they could have done more for the client (Beddoe \& Egan, 2009, p. 411), and how they could change or help the client's life. It is a natural process for individuals and in these cases supervisees to take these conversations and thoughts home; not realising the impact the client has had on their lives, until they start to reflect on their own experiences. These thoughts can impact on their families and their personal lives (Ellis, 1999, p. 70). During a controlled supervision session the supervisees could listen to others in the same predicament and listen to how they were able to resolve the issues for themselves. With the aid of a professional the group can debrief and more importantly reflect on how to move forward from their cognitive processing, by not taking these issues home. Therefore, to understand the importance of supervision you need to have experienced the power of a quality supervision session (Beddoe \& Egan, 2009, p. 411).

\section{Limitations of peer supervision}

It is important to identify what can go wrong in peer supervision groups. Peer supervision potentially has many advantages, but there are a number of potential pitfalls. Without a qualified supervisor, the group could lack structure and degenerate into gossip sessions, gripe sessions, chat sessions or discussion groups (Wonnacott, 2012, pp. 129-130). People have busy lives and may prioritise other demands on their time, which could impact on attendance at peer supervision.

Many people at peer supervision may seem more threatening than individual supervision, leading to supervisees not feeling safe enough to expose their experiences in a group setting. There could be an overabundance of advice given and other less-than-helpful responses. Without training or due attention to process, common problems mar arise in peer supervision groups (NZFVWO, 2001, pp. 53-54). bFor example, a lack of supervisor's clinical skills within the group may not be sufficient to handle the issues and debates the supervisees bring to the session. The process could become diluted, collusion could occur and the sessions could lack rigour. People could feel criticised or demoralised, leading to lack of participation or feeling bullied. Boundaries may be harder to maintain and could lead to a breach of confidentiality with information gathered from peer supervision (NZFVWO, 
2001, p. 65). Personalities or group dynamics could impact on the quality of the supervision. Individuals may dominate and others become passive. Lack of time could be a challenge if the group did not have sufficient time to discuss all issues ( $O^{\prime}$ Donoghue, 2012, p. 215).

\section{Conclusion}

The Industrial Revolution in 19th century Britain changed society's disposition towards the most vulnerable people and from these needs volunteerism emerged to support individuals in their everyday lives. From volunteerism, organisations grew to support volunteers in their everyday task to create positive changes to individuals, communities, towns and countries. Furthermore, as society changed and the complexities around everyday lives increased, volunteers started to specialise, train and become qualified professionals; from these needs professions such as social work and counselling were established. The Gregorian calendar identifies that the 21st century has ushered in a new era of volunteerism around professional accountability and training. This meant a need for an introduction of supervision following Kadushin's principles around management, education and supportive roles. These roles and how they fit into agencies' policies were considered when volunteerism was assented into New Zealand legislation. There now seems to be relevant information offered from Volunteering New Zealand around their Boards of Trustees, Code of Ethics, which is relevant to volunteers at governance level. However, there is no clear consensus around a code of ethics that encumbers all volunteers working in the social service field. As a supervisor offering peer supervision to volunteers, there is no code of ethics to set a benchmark to adhere to professional practice standards. However, the ANZASW does offer membership to volunteers in this sector at the expense of the volunteer or agency. As our society is moving toward accountability to service, there seems to be a gap in protecting the volunteer, client and agency. Therefore, identifying the needs for a professional body such as the ANZASW to support volunteers around accountability; thus providing volunteers working in the social services a code of ethics to adhere to. In addition, more thought needs to go into the discourse around social work registration and the impacts this has on the social service sector's reputation, accountability, professionalism and safety to the general public. A possible debate to put forward to the current Minister of Social Development is for a new implementation of policy to safeguard our children, profession and public against unethical practice.

\section{References}

Aotearoa New Zealand Association of Social Workers (2008). Code of ethics. Christchurch, New Zealand: Author. Aotearoa New Zealand Association of Social Workers (2012). Supervision policy. Retrieved from http:/ / anzasw. org.nz/documents /0000/0000/0548/ANZASW_Supervision_Policy.pdf.

Aotearoa New Zealand Association of Social Workers (2014). Governance 2013-2014. Retrieved from: http: / / anzasw. org.nz / about/topics / show / 60-governance-2013-2014.

Bartol, K., Martin, D., Tein, M., \& Matthews, G. (2005). Social learning theory from: Management, A Pacific Rim Focus (4th ed.). North Ryde, Australia: McGraw-Hill

Beddoe, L., \& Egan, R. (2009). Social work supervision. In M. Connolly \& L. Harms (Eds.). Social work. Contexts and practice (2nd ed., pp. 410-422). Victoria, Australia: Oxford University Press.

Beddoe, L. \& Randal, H. (1994). The New Zealand Association of Social Workers: The professional response to a decade of change. In R. Munford \& M. Nash (Eds.). Social work in Action (pp. 21-36). Palmerston North, New Zealand: The Dunmore Press Limited.

Boston, J., Dalziel, P., \& St John, S. (1999). Rebuilding an effective welfare state. In J. Boston, P. Dalziel, S. St John (Eds.), Redesigning the welfare state in New Zealand (pp. 301-316). Auckland, New Zealand: Oxford University Press.

Boston, P. (1999). New Zealand's welfare state in transition. In J. Boston, P. Dalziel, S. St John (Eds.), Redesigning the welfare state in New Zealand (pp. 3-19). Auckland, New Zealand: Oxford University Press. 
Briggs, L., \& Cromie, B. (2009). Mental Health Social Work in New Zealand. In M. Connolly \& L. Harms (Eds.). Social work. Contexts and practice (2nd ed., pp. 222-233). Victoria, Australia: Oxford University Press.

Bruce, E. \& Austin, M. (2000). Social work supervision: Assessing the past and mapping the future. The Clinical Supervisor, 19(2), 85-107.

Clermont, R. (2011). Standards of living in Britain during the industrial revolution 1770-1820. Retrieved from: http:/ / economics.uwo.ca/undergraduate/undergraduatereview/undergraduatereview02/1_Clermont.pdf.

Collins, S. (2008). Statutory social workers: Stress, job satisfaction, coping, social support and individual differences. British Journal of Social Work, 38(1), 1173-1193.

Connolly, M. (2009). Values and human rights. In M. Connolly \& L. Harms (Eds.). Social work. Contexts and practice (2nd ed., pp. 53-67). Victoria, Australia: Oxford University Press.

Court, R. (2012, July 21). Recruiting the Facebook generation. Retrieved from The New Zealand Herald website: http: / / www.nzherald.co.nz/ business / news / article.cfm?c_id=3\&objectid=10821151.

Dalley, B. (2004). Deep and dark secrets. Government responses to child abuse. In B. Dalley \& M. Tennant (Eds.), Past judgement. Social policy in New Zealand. (pp. 116-189). Dunedin, New Zealand: University of Otago Press.

Dalziel, P., \& St John, S. (1999). New role of government. In J. Boston, P. Dalziel, S. St John (Eds.), Redesigning the welfare state in New Zealand (pp. 75-92). Auckland, New Zealand: Oxford University Press.

De Vries, J. (1994). The Industrial Revolution and the Industrious Revolution. The Journal of Economic History, 54(2) 249-270

Department of Labour (n.d). Fact sheet: Volunteerism. http://www.dol.govt.nz/hs/law/quickguide/pdfs/volunteers.pdf.

Ellis, G. (1999). Social work in voluntary welfare agencies. In R. Munford \& M. Nash (Eds.). Social work in action (pp. 58-84). Palmerston North, New Zealand: The Dunmore Press Limited.

Giddens, A. (2009). Sociology (6th ed). Cambridge, United Kingdom: Polity.

Harms, L., \& Connolly, M. (2009). The art and science of social work. In M. Connolly \& L. Harms (Eds.). Social work. Contexts and practice (2nd ed., pp. 3-18). Victoria, Australia: Oxford University Press.

Hawkins, P., \& Shohet, R. (1989). Supervision in the helping profession: An individual, group, and organisation approach. London: Open University Press.

Human Rights Act 1993. Discrimination in employment matters. Retrieved from New Zealand Legislation Webpage: http: / / www.legislation.govt.nz/ act/public/1993/0082/ latest/DLM304483.html.

Jones, M. (1999). Supervisor or superhero: New role strains for frontline supervisors in human services. Asia Pacific Journal of Social Work, 9(1), 79-97.

Kane, R. (2001). Supervision in New Zealand social work. In M. Connolly (Ed.), New Zealand social work (pp. 291303). Auckland, New Zealand: Oxford University Press.

King, R., Lloyd, C., Clune, A., \& Allan, J. (2009). The experience of being a peer outreach volunteer: Benefits and challenges. Australian e-Journal for the Advancement of Mental Health, 8(1): 66-79.

Lonne, B., \& Duke, J. (2009). The registration of social workers. In M. Connolly \& L. Harms (Eds.). Social work. Contexts and practice (2nd ed., pp. 378-392). Victoria, Australia: Oxford University Press.

Massey University (2014). Postgraduate diploma in social service supervision (PGDipSocSSS) - 2014. Retrieved from Massey University's website: http: / / www.massey.ac.nz/massey/learning/programme-course-paper/programme.cfm?prog_id=93123.

Mataira, P. (1985). A bi-cultural model of social work and social work supervision. Palmerston North, New Zealand: Massey University.

McNicoll, A. (2008). Peer supervison - no-one of us knows as much as all of us. Retrieved from: http: / / www.coachingmentoring.co.nz / files / NZMC-power-of-peer-supervision-paper-2008.pdf.

Ministry of Social Development (2012a). White paper for vulnerable children, volume 1. Retrieved from: http: / / www. msd.govt.nz / documents / about-msd-and-our-work/ work-programmes / policy-development/white-paper-vulnerable-children/white-paper-for-vulnerable-children-volume-1.pdf.

Ministry of Social Development (2012b, May). Break Thru: Funding agreement practice guidelines. Retrieved from Family \& Community Services. Retrieved from Ministry of Social Development website: http://www. familyservices.govt.nz/ documents / working-with-us / funding-and-contracting/practice-guidelines-2012 / breakthru-pg-2012.pdf

Munford, R. \& Nash, M. (1994). Preface. A conversation with Merv Hancock. In R. Munford \& M. Nash (Eds.). Social work in action (pp. 9-13). Palmerston North, New Zealand: The Dunmore Press Limited.

Munson, C. (1979). Organizational authority and professional autonomy. In C. Munson (Eds.). Social work supervision. Classic statements and critical issues (pp. 177-181). New York, NY: The Free Press.

Nash, M. (1994). Social work education in Aotearoa/New Zealand. In R. Munford \& M. Nash (Eds.). Social work in action (pp. 37-57). Palmerston North, New Zealand: The Dunmore Press Limited.

Nash, M. (2009). Histories of the social work profession. In M. Connolly \& L. Harms (Eds.). Social work. Contexts and practice (2nd ed., pp. 363-377). Victoria, Australia: Oxford University Press.

New Zealand Federation of Voluntary Welfare Organisations (2001). Managing volunteers, to advance an effective voluntary welfare sector. Wellington, New Zealand: Author.

O'Brien, M. (1999). The case of the neglected triplets: Policy, class, poverty. In R. Munford \& M. Nash. Social work in action (pp. 391-409). Palmerston North, New Zealand: The Dunmore Press Limited. 
O'Donoghue, K. (1999). Professional supervision practice under new public management: A study of the perspectives of probation officers and service managers in the community probation service. (Unpublished master's dissertation). Massey University, Palmerston North, New Zealand.

O'Donoghue, K. (2012). Windows on the supervisee experience: An exploration of supervisees' supervision histories. Australian Social Work 65(2), 214-231.

Office of the Chief Social Worker (2014, May). Workload and Casework review [Fact sheet]. Child, Youth and Family.

Payne, M. (2006). What is professional social work? (2nd ed.). Chicago, USA: Lyceum Books, Inc.

Pearce, R., \& Steiner, L. (2004). Getting a grip on leadership. How to learn leadership without making all the mistakes yourself. Auckland, New Zealand: Reed Publishing.

Pierson, J., \& Thomas, M. (Eds). (2002). Value. In Collins' Internet-linked dictionary of social work (pp. 561-562). London, England: Collins Publishers.

Shulman, L. (Presenter). (2008, October 20). Models of supervision [Episode 5]. Parallel processes and honest relationships. [Audio podcast]. Retrieved from http: / / www.socialwork.buffalo.edu/podcast / episode.asp?ep=5.

Social Workers Registration Board (2008, September). Social Workers Registration Board: Code of conduct for social workers [Booklet]. N.p.: Author.

Social Workers Registration Board (2011). Covering letter: Briefing for incoming Minister for Social Development. Retrieved from the Social Workers Registration Board's website: http:/ / www.swrb.govt.nz/news-and-publications / news

Social Workers Registration Board (May, 2013). Supervision expectations for registered social workers [Policy Statement]. Author.

Social Workers Registration Board [Discussion Paper] (n.d.). Mandatory Registration Discussion Document. N.p.: Author.

Styles, E. (1979). Supervision in perspective. In C. Munson (Ed.). Social work supervision. Classic statements and critical issues (pp. 83-93). New York, NY: The Free Press.

Tennant, M. (2004). Mixed economy or moving frontier? Welfare, the voluntary sector and government. In B. Dalley \& M. Tennant (Eds.), Past judgement. Social policy in New Zealand. (pp. 39-55). Dunedin, New Zealand: University of Otago Press.

Tennant, M., O'Brien, M., \& Sanders, J. (2008). The history of the non-profit sector in New Zealand. Wellington, New Zealand: Office for the Community and Voluntary Sector.

The Employment Relations Act 2000. Key provisions. Retrieved from New Zealand Legislation webpage: ttp:/ / www.legislation.govt.nz/act/public/2000/0024/latest/DLM58323.html.

The University of Auckland (2014). Postgraduate Certificate in Professional Supervision (PGCertProfSup). Retrieved from The University of Auckland's website: https://www.auckland.ac.nz/study-options/programmes / postgraduate / 6863 / postgraduate-certificate-in-professional-supervision-pgcertprofsup.

Tsui. M. (2004). Supervision models in social work: From nature to culture. Asian Journal of Counseling, 11(1 \& 2), 7-55.

Tsui, M. (2005). Theoretical models of social work supervision. In Social work supervision context and concepts (pp. 17-32). Thousand Oaks, CA: Sage.

Tsui, M., \& Cheung, F. (2009). Social work administration revisited. A re-examination of concepts, context and content. Journal of Social Work, 9(2), 148-157.

Volunteering New Zealand (2014). Your rights as a volunteer. Retrieved http:/ / www.volunteeringnz.org.nz/volunteers/your-rights-as-a-volunteer/.

Volunteers Employment Protection Act 1973. Retrieved from New Zealand Legislation webpage: http: / / www.legislation.govt.nz/ act/public/1973/0025/latest/DLM409766.html.

Walsh-Tapiata, W., \& Webster, J. (2004). Do you have a supervision plan? Te Komako III Social Work Review XVI(2), 15-19.

Walsh, P., \& Brosnan, P. (1999). Redesigning industrial relations: The Employment Contracts Act and its consequences. In J. Boston, P. Dalziel, S. St John (Eds.), Redesigning the welfare state in New Zealand (pp. 117-133). Auckland, New Zealand: Oxford University Press.

Weber, M., \& Tofi, H.J. (2007). Postgraduate social work management education in Aotearoa New Zealand: A unique framework for study of management. Aotearoa New Zealand Social Work Review, 48-57.

Weld, N. (2012). A practical guide to transformative supervison for the helping professions amplifying insight. Philadelphia, PA: Jessica Kingsley Publications.

Weston, D., Burton, L., \& Kowalski, R. (2006). Psychology. Australian and New Zealand Edition. Queensland, Australia: Wiley \& Sons Ltd.

Wintec (2014). Postgraduate Certificate in Professional Supervision (level 8). Retrieved from Wintec website: http: / / www.wintec.ac.nz/courses/SitePages/post-graduate-certificate/ professional-supervision.aspx

Wonnacott, J. (2012). Mastering social work supervision. London, England: Jessica Kingsley Publications. 